\title{
ОБЩЕСТВЕННЫЕ ОБСУЖДЕНИЯ ВОПРОСОВ ПРОТИВОДЕЙСТВИЯ КОРРУПЦИИ КАК ФОРМА ВЗАИМОДЕЙСТВИЯ ИНСТИТУТОВ ГРАЖДАНСКОГО ОБЩЕСТВА С ОРГАНАМИ ПУБЛИЧНОЙ ВЛАСТИ ПРИ ОСУЩЕСТВЛЕНИИ ОБЩЕСТВЕННОГО КОНТРОЛЯ
}

Аннотация: Предметом проведенного исследования выступают общественные обсуждения вопросов противодействия коррупщи как форма взаимодействия институтов гражданского общества с органами публичной власти при осуществлении общественного контроля.Задачи исследования: а) раскрыть содержание общественных обсуждений вопросов противодействия коррупии как формы взаимодействия институтов гражданского общества с органами публичной власти при осуществлении общественного контроля; б) провести структурный анализ основных элементов общественных обсуждений вопросов противодействия коррупции как формы взаимодействия институтов гражданского общества с органами публичнй власти при осуществлении общественного контроля; в) предложить собственное определение общественных обсуждений вопросов противодействия коррупиии как формы взаимодействия институтов гражданского общества с органами публичной власти при осуществлении общественного контроля. Методологической основой проведенного исследования является диалектический материализм и основанные на ним общенаучные методы познания, в том числе структурный анализ и иные. Научная новизна проведенного исследования заключается в том, что автором впервые в российской научнойлитературе рассмотрены общественные обсуждения вопросов противодействия коррупци как форма взаимодействия институтов гражданского общества с органами публичной власти при осуществлении общественного контроля, раскрыто их содержание и выработана научная дефиниия, которая может быть использована для осуществления дальнейших научных исследований.

Abstract: The object of studies involves public discussion of the issues of fighting corruption as the form of interaction of the civil society institutions with the public government bodies in the process of implementation of public control. The goals of the study involve the following: 1) discussing elements of public discussion on fighting corruption as the form of interaction of the civil society institutions with the public government bodies in the process of public control implementation; 2) providing structural analysis of the main elements of the public discussions of the issues regarding fighting corruption as a form of interaction of the civil society institutions with the public government bodies in the process of public control implementation; 2) to offer the vision of the author regarding public discussions on issues regarding fighting corruption as a form of interaction of the civil society institutions with the public government bodies in the process of public control implementation. The methodological basis for the study involves dialectic materialism and the general scientific cognition methods based upon it, including structural analysis, etc. The scientific novelty of the study is due to the fact that for the first time in the Russian scientific literature the author views the public discussion of issues of fighting corruption as a form of interaction of the civil society institutions with the public government bodies in the process of public control implementation, discussing its contents, providing its scientific definition, which may be used for the further scientific studies. Ключевые слова: Коррупиия, противодействие коррупиии, антикоррупиионная политика, общественные обсуждения, общественный контроль, органы публичной власти, институты гражданского общества, взаимодействие, народные обсуждения, публичные обсуждения.

Keywords: corruption, fighting corruption, anti-corruption policy, public discussion, public control, public government bodies, civil society institutions, interaction, public discussions, public hearings. 
DOI: 10.7256/1811-9018.2014.10.12998

При цитировании этой статьи сноска на доі обязательна

\section{Право и политика $10(178) \cdot 2014$}

$\Pi$ ротиводействие коррупции как сложная многоуровневая система сдерживания коррупции на социально терпимом уровне требует не только значительных ресурсов, но и взаимодействия различных государственных и общественных структур. Такое взаимовыгодное взаимодействие предусмотрено действующим российским законодательством как при организации и проведении совместных мероприятий органов публичной власти с институтами гражданского общества, так и при осуществлении контрольных функций за органами публичной власти со стороны институтов гражданского общества. В качестве одной из самостоятельных форм взаимодействия органов публичной власти и институтов гражданского общества при осуществлении общественного контроля федеральный законодатель определил общественные обсуждения общественно значимых вопросов и важнейших управленческих решений. Однако вне поля зрения отечественного законодателя остались вопросы использования общественных обсуждений как средства общественного контроля в отдельных сферах жизнедеятельности, в том числе и сфере реализации государственной политики противодействия коррупции. Хотя о специфике использования общественных обсуждений в отдельных сферах жизнедеятельности уже имеются научные исследования и опубликованы их результаты, ${ }^{1}$ которые, к сожалению, не затрагивают возможности использования этого инструмента в

\footnotetext{
${ }^{1}$ См., например: Околеснова О.А. Информационно-правовые аспекты общественных обсуждений как формы общественного контроля // European Social Science Journal. - 2012. - №11-1 (27). - C.537-549; Захаров А.К. Общественное обсуждение и процедура принятия и внесения изменений в устав городского округа // Юристъ-Правоведъ. - 2011. - №5 (148). - С.98-100; Липчинская М.А. Об общественном обсуждении законопроектов как форма участия граждан Российской Федерации в управлении делами государства // Правовая политика и правовая жизнь. - 2011. - №2. - С.12-18; Сивицкий B.A. Общественные обсуждения законопроектов: демократия или государственный рационализм // Юридическая техника. - 2014. №8. - С.393-396; Гайнутдинова Г.Х., Мингазова Н.М. Различия в процедурах общественных слушаний и общественных слушаний // Экологический консалтинг. - 2012. - №2. - С.15-21; Леонов Ю.С. Об общественном обсуждении стратегии государственной национальной политики Российской Федерации // Современные исследования социальных проблем. - 2013. - №1 (21). - С.22; Хохлова Е.А. Общественное обсуждение законопроектов и важнейших вопросов государственной и/или общественной жизни: конституционноправовое регулирование // Конституционное и муниципальное право. - 2013. - №4. - С.47-59; Ахметова С.А. Общественное обсуждение «Инновационная политика в Хабаровском крае» // Ученые записки Комсомольского-на-Амуре государственного технического университета. - 2014. - Т.1. - №2. - С.117-118 и др.
}

сфере противодействия коррупции. Имеется лишь предложения по использованию общественных обсуждений как средства прозрачности и противодействия коррупции в системе государственных закупок. ${ }^{2}$ Все это свидетельствует о необходимости проведения научных исследований института общественных обсуждений по вопросам противодействия коррупции как инструмента общественного контроля за реализацией государственной политики противодействия коррупции.

Исследование института общественных обсуждений по вопросам противодействия коррупции как формы взаимодействия органов публичной власти и институтов гражданского общества при осуществлении общественного контроля не возможно без обращения к определению базового термина «общественные обсуждения». В соответствии с федеральным законом «Об основах общественного контроля в Российской Федерации», под общественным обсуждением понимается используемое в целях общественного контроля публичное обсуждение общественно значимых вопросов, а также проектов решений органов государственной власти, органов местного самоуправления, государственных и муниципальных организаций, иных органов и организаций, осуществляющих в соответствии с федеральными законами отдельные публичные полномочия, с обязательным участием в таком обсуждении уполномоченных лиц указанных органов и организаций, представителей граждан и общественных объединений, интересы которых затрагиваются соответствующим решением. ${ }^{3}$ Хотя в российском региональном законодательстве имеются и другие подходы к определению «общественные обсуждения», ${ }^{4}$ которые иногда именуются другими

\footnotetext{
${ }^{2}$ Порошин С.A. Коррупция в системе государственных закупок: проблемы и пути выхода // Вопросы управления. - 2013. - №2 (4). - С.051-057.

${ }^{3}$ Об основах общественного контроля в Российской Федерации: Федеральный закон от 21 июля 2014 года №212-Ф3 // Собрание законодательства РФ. - 2014. - №30 (часть 1). - Ст.4213.

${ }^{4} \mathrm{O}$ законодательной деятельности в Кемеровской области: Закон Кемеровской области от 23 июня 2003 года №33-О3 (в ред. от 04.04.2013 №41-О3) // Кузбасс. - 2003. - 9 июля; О порядке установления публичных сервитутов на территории Ставропольского края: Закон Ставропольского края от 21 декабря 2007 года №75-кз (в ред. от 12.10.2010 №81-кз) // Сборник законов и других правовых актов Ставропольского края. - 2008. - №3-4. - Ст. 6961; О Гражданской ассамблее Красноярского края: Закон Красноярского края от 9 июня 2011 года №12-5975 (в ред. от 04.04.2013 №4-1149) // Наш Красноярский край. - 2011. - 24 июня.
} 
Общественные коммуникации

словосочетаниями - «народные обсуждения» ${ }^{5}$ или «публичные обсуждения». 6

Для более детального рассмотрения общественных обсуждений как инструмента общественного контроля и возможности его использования в сфере противодействия коррупции мы проведем структурный анализ этого вида деятельности. С этой целью выделим основные структурные элементы общественных обсуждений как одной из форм взаимодействия органов публичной власти с институтами гражданского общества при осуществлении ими общественного контроля. В качестве таких элементов, на наш взгляд, выступают: объект, предмет и цели общественных обсуждений, субъект общественных обсуждений, а также процедурные и технологические вопросы этого вида взаимодействия.

Обратившись к определению общественных слушаний как правовой категории в сфере осуществления общественного контроля, мы обнаруживаем, что их основным объектом выступают:

а) органы публичной власти,

б) государственные и муниципальные организации, осуществляющие в соответствии с федеральными законами отдельные публичные полномочия;

в) иные органы и организации, осуществляющие в соответствии с федеральными законами отдельные публичные полномочия.

\footnotetext{
${ }^{5} \mathrm{O}$ народном обсуждении проектов нормативных правовых актов Калужской области и важных вопросов государственной и общественной жизни Калужской области: Закон Калужской области от 26 апреля 2013 года №420-О3 //Весть документы. - 2013. - 8 мая; О народном обсуждении наиболее важных вопросов государственной жизни Республики Татарстан и местного значения: Закон Республики Татарстан от 6 августа 2003 года №26-ЗРТ (в ред. от 12.12.2005 №120-3РТ) // Республика Татарстан. - 2003. - 9 авг; О народном обсуждении: Уставный закон Красноярского края от 26 марта 2009 года №8-3076 // Наш Красноярский край. - 2009. - 3 апр.

${ }^{6}$ Об утверждении Временного порядка публичного обсуждения проектов постановлений Губернатора Ленинградской области, проектов постановлений Правительства Ленинградской области и проектов приказов органов исполнительной власти Ленинградской области по вопросам государственного регулирования предпринимательской деятельности в Ленинградской области: Постановление Губернатора Ленинградской области от 11 октября 2011 года №97-пг // Вестник Правительства Ленинградской области. - 2011. - 16 нояб.; Об утверждении Порядка публичного обсуждения проектов Законов Республики Марий Эл в области бюджетного и налогового законодательства: Постановление Правительства Республики Марий Эл от 28 июня 2005 года №170 // Собрание законодательства Республики Марий Эл. - 2005. - №7. - Ст.322; Об утверждении Положений о публичном обсуждении и порядке проведения публичных консультаций с предпринимательским сообществом вопросов регулирования экономической и инвестиционной деятельности: Указ Президента Республики Саха (Якутия) от 26 января 2012 года №1197 // Якутские ведомости. 2012. - 1 февр.
}

Предметная область общественных слушаний как формы осуществления общественного контроля за деятельностью органов публичной власти ограничивается лишь двумя направлениями: обсуждением общественно значимых вопросов деятельности объектов общественного контроля и обсуждением проектов принимаемых ими управленческих решений.

Как показывает региональная практика общественного контроля, предметом общественных обсуждений как средства общественного контроля наиболее часто выступают проекты нормативных правовых актов. В отдельных нормативных правовых актах субъектах Российской Федерации и муниципальных образований в качестве предмета общественных обсуждений обозначаются важнейшие документы стратегического и программно-целевого планирования.?

Современная российская практика общественных обсуждений чаще всего касается вопросов правотворческой деятельности, и именно это направление наиболее полно регламентировано как на федеральном уровне, ${ }^{8}$

\footnotetext{
${ }^{7}$ О системе документов стратегического и программно-целевого планирования Томской области: Закон Томской области от 14 сентября 2009 года №177-О3 (в ред. от 9.02.2012 №9-О3) // Собрание законодательства Томской области. - 2009. - №31 (153); Об утверждении порядка проведения публичный обсуждения проектов республиканских целевых программ: Постановление Правительства Чеченской Республики от 28 декабря 2010 года №250 // Вести Республики. - 2011. - 6 декаб.; Об утверждении Порядка проведения публичных обсуждений проектов муниципальных программ: Постановление Администрации муниципального образования Кольский район Мурманской области от 27 сентября 2013 года №1374 // Кольское слово. - 2013. - 3, 10 октяб.; Об утверждении порядка проведения публичных обсуждений проектов долгосрочных целевых программ: Постановление администрации Рыбинского муниципального района Ярославской области от 10 декабря 2012 года №2213 // Новая жизнь. - 2012. - 13 декаб.; Об утверждении Порядка проведения публичного обсуждения проектов государственных программ Чувашской Республики и о внесении изменений в некоторые постановления Кабинета Министров Чувашской Республики: Постановление Кабинета Министров Чувашской Республики от 31 декабря 2011 года №675 // Собрание законодательства Чувашской Республики. - 2011. - №12 (часть 3). - Ст.1404; Об утверждении Порядка проведения публичного обсуждения государственных программ Брянской области: Постановление Правительства Брянской области от 4 августа 2014 года №358-п // Официальная Брянщина. - 2014. - 8 авг.

${ }^{8}$ Об общественном обсуждении проектов федеральных конституционных законов и федеральных законов: Указ Президента Российской Федерации от 9 февраля 2011 года №167 // Собрание законодательства РФ. - 2011. - №7. - Ст. 939; Об утверждении Правил проведения общественного обсуждения проектов федеральных конституционных законов и федеральных законов: Постановление Правительства Российской Федерации от 22 февраля 2012 года №159// Собрание законодательства РФ. - 2012. - №10. - Ст. 1247; О порядке раскрытия федеральными органами исполнительной власти информации о подготовке проектов нормативных правовых актов и результатах их общественного обсуждения: Постановление
} 
DOI: $10.7256 / 1811-9018.2014 .10 .12998$

При цитировании этой статьи сноска на dоі обязательна

\section{Право и политика 10 (178) • 2014}

так и региональном ${ }^{9}$ и муниципальном уровнях.$^{10}$ Более того в отдельных региональных законах о противодействии коррупции общественные обсуждения проектов областных законов являются средством профилактики коррупции в сфере правотворчества. ${ }^{11}$ В законодательстве Томской области о правовом регулировании процедур правотворчества общественные обсуждения являются обязательным элементом антикоррупционного стандарта нормотворческой деятельности. ${ }^{12}$

Как показывает практика общественных обсуждений в сфере противодействия коррупции, наиболее часто встречаются общественные обсуждения наиболее важных нормативных правовых актов по вопросам противодействия коррупции федерального и региональ-

Правительства Российской Федерации от 25 августа 2012 года №851 //Собрание законодательства РФ. - 2012. - №36. - Ст. 4902; Об утверждении состава нормативных правовых актов и иных документов, включая программные, разрабатываемых федеральными органами исполнительной власти, которые не могут быть приняты без предварительного обсуждения на заседаниях общественных советов при этих федеральных органах исполнительной власти: Постановление Правительства Российской Федерации от 1 сентября 2012 года №877 // Собрание законодательства РФ. 2012. - №37. - Ст. 4997.

9 О правовых актах города Москвы: Закон города Москвы от 8 июля 2009 года №25 // Ведомости Московской городской Думы. - 2009. - №8. - Ст. 214; Об общественном обсуждении проектов нормативных правовых актов Вологодской области: Закон Вологодской области от 30 января 2013 года №2980-О3 // Красный Север. - 2013. - 2 февр.; Об общественном обсуждении проектов законов Республики Башкортостан: Закон Республики Башкортостан от 4 декабря 2012 года №605-з // Ведомости Государственного Собрания - Курултая, Президента и Правительства Республики Башкортостан. - 2012. - 36(402). - Ст. 1682; Об общественном обсуждении проектов нормативных правовых актов Архангельской области: Закон Архангельской области от 29 октября 2012 года №562-34-О3 // Волна. - 2012. - 30 октяб.; Об общественном обсуждении проектов законов Калининградской области и вопросов, требующих законодательного решения: Закон Калининградской области от 17 мая 2004 года №399 // Российская газета. Запад России. - 2004. - 8 июня; Об утверждении порядка публичных обсуждений проектов нормативных правовых актов Губернатора Калининградской области и Правительства Калининградской области: Указ Губернатора Калининградской области от 12 августа 2011 года №125 // Калининградская правда. - 2011 - 17 авг.

${ }^{10}$ Об утверждении Порядка вынесения на публичное обсуждение проектов нормативных правовых актов, затрагивающих интересы граждан и организаций: Постановление главы Судогодского района Владимирской области от 12 сентября 2007 года №1449 // Судога и судогодцы. - 2007. - 19 сентяб.

${ }^{11}$ О мерах по предупреждению коррупции в Сахалинской области: Закон Сахалинской области от 1 августа 2008 года №85-3О (в ред. от 30.06. 2011 №61-3О) // Губернские новости. - 2008. - 8 авг.

${ }^{12} \mathrm{O}$ нормативных правовых актах Томской области: Закон Томской области от 7 марта 2002 года №9-О3 (в ред. от 9.02.2012 №9-О3) // Официальные ведомости Государственной Думы Томской области. - 2002. - 20 марта. - №4 (65). ного уровня. Здесь общественные обсуждения в первую очередь должны касаться наиболее значимых вопросов: формирования стратегии противодействия коррупции на долгосрочную перспективу и принятие основных федеральных и региональных законов о противодействии коррупции. Опыт таких бурных обсуждений проектов антикоррупционных законов в Российской Федерации уже имеется, для этого необходимо вспомнить хотя бы общественные обсуждение проекта закона Российской Федерации «О борьбе с коррупцией», происходившего в 1993 году среди представителей юридического сообщества и политиков, после его официального опубликования, ${ }^{13}$ в которых приходилось участвовать и автору этих строк. Менее известны общественные обсуждения проектов региональных антикоррупционных нормативных правовых актов, но и они имеются. Так, в 2004 году по решению Президента Республики Татарстан была начата разработка Стратегии антикоррупционной политики в Республики Татарстан, ${ }^{14}$ в результате которого к началу 2005 года специальной комиссией был подготовлен проект этого документа. Разработанный проект Стратегии антикоррупционной политики Республики Татарстан не только проходил согласование с органами публичной власти внутри этого субъекта Российской Федерации, но и неоднократно публично обсуждался среди политиков, ученых и юридической общественности с предоставлением рекомендаций по его совершенствованию. Только после того как общественные обсуждения и согласование документа внутри органов публичной власти Республики Татарстан было завершено в апреле 2005 года этот документ в окончательном виде был утвержден ${ }^{15}$ и действует до настоящего времени. В настоящее время государственными органами Республики Татарстан уже инициируется вопрос о начале разработки новой антикоррупционной стратегии этого субъекта Российской Федерации, которая, в случае принятия решения о начале разработки, несомненно, пройдет этап общественных обсуждений.

Для полноты картины необходимо обратить внимание, что организаторами общественных об-

\footnotetext{
${ }^{13}$ О проекте закона Российской Федерации «О борьбе с коррупцией»: Постановление Верховного Совета Российской Федерации от 21 марта 1993 года №4718-1 // Российская газета. - 1993. - 16 апр.

${ }^{14} \mathrm{O}$ комиссии по разработке стратегии антикоррупционной политики в Республике Татарстан: Указ Президента Республики Татарстан от 12 июля 2004 года №УП-472 // Ведомости Государственного Совета Татарстана. - 2004. - №7 (ІІ часть). - Ст.495.

${ }^{15}$ О Стратегии антикоррупционной политики Республики Татарстан: Указ Президента Республики Татарстан от 8 апреля 2005 года №УП127 // Ведомости Государственного Совета Татарстана. - 2005. - №4 (II часть). - Ст.460.
} 
суждений вопросов противодействия коррупции, как правило, выступают заинтересованные органы публичной власти или их структурные подразделения, специализирующиеся на вопросах противодействия коррупции. Например, в законотворческом органе Ханты-Мансийского автономного округа - Югры организация (инициирование) и проведение общественных слушаний по вопросам противодействия коррупции возлагается на Комиссию по противодействию коррупции при этом органе государственной власти. ${ }^{16}$ Вместе с тем, Общественная палата этого субъекта Российской Федерации, выполняя контрольные функции, также организует и осуществляет общественные обсуждения проектов региональных нормативных правовых актов. Например, 10 января 2014 года она проводила общественные обсуждения проекта Плана противодействия коррупции в Ханты-Мансийском автономном округе - Югре на 2014 - 2015 годы.

В качестве участников общественных обсуждений привлекаются представители общественных организаций, научных и образовательных учреждений, экспертных сообществ, общественных палат субъектов Российской Федерации и общественных советов органов государственной власти и общественных палат (советов) муниципальных образований. В нормативных правовых актах, регулирующих деятельность некоторых общественных организаций уполномоченных осуществлять общественный контроль, прямо предусмотрено участие их представителей в обсуждениях вопросов противодействия коррупции в органах публичной власти. ${ }^{17}$

Обязательными участниками общественных обсуждений являются уполномоченные лица органов публичной власти, государственных и муниципальных организаций, иных органов и организаций, осуществляющих отдельные публичные полномочия. Именно их присутствие и активное участие в процессе общественных обсуждений является залогом плодотворных дискуссий и выработки конструктивных итоговых документов (резолюций, решений, рекомендаций).

Предметом общественных обсуждений по вопросам противодействия коррупции, в силу сложившейся

${ }^{16} \mathrm{O}$ комиссии по противодействию коррупции Думы ХантыМансийского автономного округа - Югры: Постановление Думы Ханты-Мансийского автономного округа - Югры от 28 октября 2009 года №4439 (в ред. от 25.05.2014 №1366) // Собрание законодательства Ханты-Мансийского автономного округа - Югры. - 2009. - №10 (часть II). - Ст.940.

17 Об общественном совете при департаменте территориального развития Ярославской области: Приказ Департамента территориального развития Ярославской области от 21 июля 2014 года №4 // Документы-Регион. - 2014. - 1 авг. практики, выступают проекты важнейших региональных и муниципальных нормативных правовых актов в сфере противодействия коррупции (антикоррупционных стратегий (концепций) и целевых программ противодействия коррупции). Например, в статье 8 Закона Республики Дагестан «О противодействии коррупции в Республике Дагестан» прямо предусмотрено что, проект антикоррупционной программы Республики Дагестан опубликовывается в средствах массовой информации для всенародного обсуждения. ${ }^{18}$ Хотя региональный законодатель не определил организатора и исполнителей общественных обсуждений проекта антикоррупционной программы, но в соответствии с опубликованным докладом о деятельности Общественной палаты Республики Дагестан именно этот орган регионального общественного контроля их осуществил также добросовестно, как и проект регионального закона о противодействии коррупции. ${ }^{19}$

Опытом общественных обсуждений действующих антикоррупционных программных нормативных правовых актов обладает Краснодарская краевая общественная организация «Антикоррупционный консорциум», которая 25 апреля 2013 года на своем заседании обсуждала утвержденную губернатором долгосрочную краевую программу противодействия коррупции на 2013-2015 годы с участием представителей региональных органов публичной власти. Во время общественных слушаний присутствовали должностные лица органов публичной власти не только принимавшие участие в её разработке, но и обеспечивающие исполнение этого антикоррупционного документа. ${ }^{20}$

На наш взгляд, предмет общественных обсуждений в сфере противодействия коррупции должен охватывать более широкий круг вопросов противодействия коррупции. Важнейшим направлением таких обсуждений должны стать общественные обсуждения результатов антикоррупционной деятельности органов публичной власти. Это обусловлено тем, что региональным антикоррупционным законодательством предусмотрена подготовка региональных и муниципальных ежегодных докладов (отчетов) по вопросам противодействия

\footnotetext{
${ }^{18} \mathrm{O}$ противодействии коррупции в Республике Дагестан: Закон Республики Дагестан от 7 апреля 2009 года №21 (в ред. от 12.03.2013 №12) // Собрание законодательства Республики Дагестан. - 2009. - №7. - Ст. 275.

${ }^{19} \mathrm{O}$ деятельности Общественной палаты Республики Дагестан и состоянии гражданского общества в Республике Дагестан: Доклад председателя Общественной палаты Республики Дагестан А.М. Муртазалиева. - Махачкала, 2008. - С.5, 12.

${ }^{20}$ www.consortium-kuban.ru
} 
DOI: 10.7256/1811-9018.2014.10.12998

При цитировании этой статьи сноска на dоі обязательна

\section{Право и политика $10(178) \cdot 2014$}

коррупции. Следует иметь в виду, что формирование (создание) и обнародование ежегодных докладов (отчетов) о результативности противодействия коррупции на региональном и муниципальном уровнях предусмотрены в значительной доле региональных законов о противодействии коррупции. Эти доклады иногда по инициативе органов публичной власти публикуются в региональных и муниципальных средствах массовой информации ${ }^{21}$ и размещаются на официальных сайтах этих органов. Хотя в некоторых субъектах Российской Федерации предусмотрены и специальные отчеты по реализации региональных программ по противодействию коррупции. ${ }^{22}$ Вместе с тем, широких и резонансных общественных обсуждений этих важнейших региональных и муниципальных итоговых документов по вопросам противодействия коррупции не происходит. Исключением из этого правила оказался Краснодарский край, где уже упоминаемой нами ранее региональной общественной организацией «Антикоррупционный консорциум», в апреле 2013 года было организовано и осуществлено публичное обсуждение отчета Министерства экономики Краснодарского края о реализации мер антикоррупционной политики с участием руководителей этого регионального ведомства. ${ }^{23}$

Необходимо отметить, что антикоррупционная деятельность многообразна и многопредметна. Так, в отдельных субъектах Российской Федерации нормативными правовыми актами предусматривается специальные общественные обсуждения, предметом которых является «выявление фактов коррупционных правонарушений» в определенных сферах жизнедеятельности. ${ }^{24}$ Насколько результативны эти региональные обществен-

${ }^{21}$ О коррупции в Республике Калмыкия: Доклад Комиссии по предупреждению и противодействию коррупции в Республики Калмыкия от 18 октября 2012 года №1 // Хальмг унн. - 2012. - 7 нояб.; Об утверждении Доклада о противодействии коррупции в Волгоградской области в 2009 году: Постановление Администрации Волгоградской области от 28 июня 2010 года №295-п // Волгоградская правда. $-2010 .-7$ июля.

22 Об утверждении итогового отчета о реализации долгосрочной целевой программы Московской области «Противодействие коррупции в Московской области на 2009-2011 годы»: Постановление Правительства Московской области от 31 июля 2012 года №954/27 // Информационный вестник Правительства Московской области. - 2012. - 29 октяб.

${ }^{23}$ www.consortium-kuban.ru

${ }^{24}$ Об утверждении Порядка общественного обсуждения размещения заказов на поставку товаров, выполнение работ, оказание услуг для государственных нужд Ярославской области на сумму свыше 1 млрд. рублей: Постановление Правительства Ярославской области от 31 января 2013 года №38-п // Документы-Регион. - 2013. -8 февр. ные слушания даже предположить сложно, поскольку органы публичной власти, организующие и проводящие эти общественные слушания, не обнародуют их результатов. Следовательно, предметом общественных обсуждений вопросов противодействия коррупции как формы взаимодействия органов публичной власти и институтов гражданского общества при осуществлении общественного контроля являются:

a) проекты важнейших нормативных правовых актов, направленных на организацию и осуществление противодействия коррупции в органах публичной власти;

б) нормативные правовые акты, регулирующие деятельность по противодействию коррупции в органах публичной власти;

в) результаты противодействия коррупции в органах публичной власти;

г) иные важнейшие вопросы противодействия коррупции, предусмотренные нормативными правовыми актами о противодействии коррупции и/или об общественном контроле.

На наш взгляд, основной целью общественных обсуждений вопросов противодействия коррупции как средства общественного контроля является общая цель общественного контроля - повышение эффективности противодействия коррупции в органах публичной власти, а дополнительной (факультативной) целью может выступать - привлечение внимания институтов государства и гражданского общества к проблемам противодействия коррупции.

Рассмотрев структуру общественных обсуждений как средства осуществления общественного контроля в сфере противодействия коррупции необходимо отметить следующее. Во-первых, общественные обсуждения как инструмент общественного контроля в сфере противодействия коррупции - это деятельность по обсуждению заинтересованными лицами (органами публичной власти, институтами гражданского общества, населением) наиболее значимых вопросов, связанных с формированием и реализацией государственной политики противодействия коррупции в целях повышения её эффективности и привлечение внимания государства и общества к этой проблеме. Во-вторых, в Российской Федерации ещё не сложилась практика регулярных общественных обсуждений вопросов противодействия коррупции в силу различных причин. Таковыми можно признать, например, организационные причины, связанные с низкой активностью (инертностью) институтов гражданского общества в сфере противодействия 
DOI: $10.7256 / 1811-9018.2014 .10 .12998$

При цитировании этой статьи сноска на доі обязательна

Общественные коммуникации

коррупции либо правовые причины, обусловленные отсутствием правового регулирования механизмов общественных обсуждений в сфере противодействия коррупции. В-третьих, низким уровнем теоретиче- ских и прикладных исследований, связанных с использованием общественных обсуждений в качестве средства общественного контроля в сфере противодействия коррупции.

\section{Библиография:}

1. Ахметова С.А. Общественное обсуждение «Инновационная политика в Хабаровском крае» // Ученые записки Комсомольского-на-Амуре государственного технического университета. - 2014. - Т.1. - №2. - C.117-118.

2. Гайнутдинова Г.Х., Мингазова Н.М. Различия в процедурах общественных слушаний и общественных слушаний // Экологический консалтинг. - 2012. - №2. - С.15-21.

3. Захаров А.К. Общественное обсуждение и процедура принятия и внесения изменений в устав городского округа // Юристъ-Правоведъ. - 2011. - №5 (148). - С.98-100.

4. Леонов Ю.С. Об общественном обсуждении стратегии государственной национальной политики Российской Федерации // Современные исследования социальных проблем. - 2013. - №1 (21).

5. Липчинская М.А. Об общественном обсуждении законопроектов как форма участия граждан Российской Федерации в управлении делами государства // Правовая политика и правовая жизнь. - 2011. - №2. - С.12-18.

6. О деятельности Общественной палаты Республики Дагестан и состоянии гражданского общества в Республике Дагестан: Доклад председателя Общественной палаты Республики Дагестан А.М. Муртазалиева. - Махачкала, 2008. - С.5, 12.

7. Околеснова О.А. Информационно-правовые аспекты общественных обсуждений как формы общественного контроля // European Social Science Journal. - 2012. - №11-1 (27). - C.537-549.

8. Порошин С.А. Коррупция в системе государственных закупок: проблемы и пути выхода // Вопросы управления. - 2013. - №2 (4). - С.051-057.

9. Сивицкий В.А. Общественные обсуждения законопроектов: демократия или государственный рационализм // Юридическая техника. - 2014. - №8. - С.393-396.

10. 10. Хохлова Е.А. Общественное обсуждение законопроектов и важнейших вопросов государственной и/или общественной жизни: конституционно-правовое регулирование // Конституционное и муниципальное право. - 2013. - №4. - С.47-59.

11. Астанин В.В. Об эффективных механизмах взаимодействия государства с гражданским обществом в сфере противодействия коррупции. // Административное и муниципальное право. - 2011. - 4. - С. 5-8.

12. Харитонов А.Н. Рецензия на книгу: Н.А. Коломытцев, О.Н. Коломытцева Современные проблемы общественного контроля в России: монография. - СПб.: Издательство Юридического института (Санкт-Петербург). 2014. - 220 с. // Административное и муниципальное право. - 2014. - 7. - С. 696-699. DOI: 10.7256/1999-2807.2014.7.12076.

13. Кабанов П.А. Антикоррупционный мониторинг в муниципальном образовании: правовое регулирование, организация и проведение // NB: Административное право и практика администрирования. - 2013. - № 6. - C.44-53. DOI: 10.7256/23069945.2013.6.9016. URL: http://e-notabene.ru/al/article_9016.html

14. Кабанов П.А.. Антикоррупционное образование как правовая категория регионального антикоррупционного законодательства: опыт критического анализа // Полицейская деятельность. - 2014. - № 1. - C. 104-107. DOI: 10.7256/22221964.2014.1.10653

15. Кабанов П.А. Правовые средства формирования и обеспечения реализации государственной политики противодействия коррупции в субъектах Российской Федерации: некоторые вопросы повышения качества // NB: Вопросы права и политики. - 2014. - № 8. - C.36-47. DOI: 10.7256/2305-9699.2014.8.12004. URL: http://e-notabene.ru/lr/article_12004.html

16. Кабанов П.А. Юридико-лингвистическая неопределенность как предмет антикоррупционной экспертизы нормативных правовых актов и проектов нормативных правовых актов // NB: Административное право и практика администрирования. - 2014. - № 3. - C.61-71. DOI: 10.7256/2306-9945.2014.3.12055. URL: http://e-notabene.ru/al/article_12055.html

17. Кабанов П.А. Компромиссы при реализации государственной политики Российской Федерации в сфере противодействия коррупции как средства разрешения правовых противоречий // NB: Вопросы права и политики. - 2014. - № 7. - C.66-78. DOI: 10.7256/2305-9699.2014.7.12702. URL: http://e-notabene.ru/lr/article_12702.html

18. Кабанов П.А. Организация и осуществление ведомственного контроля за реализацией государственной политики противодействия коррупции в регионах Российской Федерации // NB: Вопросы права и политики. - 2014. - № 6. - C.130145. DOI: 10.7256/2305-9699.2014.6.12236. URL: http://e-notabene.ru/lr/article_12236.html

19. Кабанов П.А. Антикоррупционные программы субъектов Российской Федерации как средства противодействия коррупции: опыт критического анализа // NB: Проблемы общества и политики. - 2014. - № 5. - C.42-70. DOI: 10.7256/23060158.2014.5.12103. URL: http://e-notabene.ru/pr/article_12103.html

20. Кабанов П.А.. Рецензия на книгу: Будатаров С.М. Антикоррупционная экспертиза правовых актов и их проектов: понятие, порядок проведения: специализированный учебный курс / С.М. Будатаров; Саратовский Центр по исследованию проблем организованной преступности и коррупции. - Саратов: Изд-во ФГБОУ ВПО «Саратовская государственная юридическая академия», 2013. - 120 с. // Административное и муниципальное право. - 2013. - № 7. - C. 104-107. DOI: $10.7256 / 1999-2807.2013 .7 .9054$ 


\section{Право и политика $10(178) \cdot 2014$}

21. Кабанов П.А. Квалификационные требования к членам Комиссий по соблюдению требований к служебному поведению государственных (муниципальных) служащих и урегулированию конфликта интересов не занимающим должности государственной (муниципальной) службы // NB: Административное право и практика администрирования. - 2013. - № 3. - C.25-33. DOI: 10.7256/2306-9945.2013.3.657. URL: http://e-notabene.ru/al/article_657.html

22. Кабанов П.А.. Организационно-правовые вопросы подготовки и осуществления антикоррупционного мониторинга в субъектах Российской Федерации // Административное и муниципальное право. - 2013. - № 7. - C. 104-107. DOI: 10.7256/1999-2807.2013.7.8934

23. Кабанов П.А. Ознакомление с материалами участников заседания Комиссии по соблюдению требований к служебному поведению государственных (муниципальных) служащих и урегулированию конфликта интересов, поступившими на рассмотрение: процедурные вопросы // NB: Административное право и практика администрирования. - 2012. - № 1. C.17-23. DOI: 10.7256/2306-9945.2012.1.376. URL: http://e-notabene.ru/al/article_376.html

24. Кабанов П.А.. Об обеспечении реализации отдельных положений антикоррупционного законодательства на муниципальном уровне // Административное и муниципальное право. - 2013. - № 6. - C. 104-107. DOI: 10.7256/1999-2807.2013.06.11

25. Кабанов П.А. Дискуссионные вопросы современной российской политической криминологии // NB: Вопросы права и политики. - 2012. - № 4. - C.240-267. DOI: 10.7256/2305-9699.2012.4.220. URL: http://e-notabene.ru/lr/article_220.html

26. Кабанов П.А. Президиум Совета при Президенте Российской Федерации и образуемые им рабочие органы как высшие федеральные специализированные антикоррупционные учреждения: вопросы повышения качества правового регулирования и эффективности их деятельности // NB: Административное право и практика администрирования. - 2013. - № 2. - C.91-104. DOI: 10.7256/2306-9945.2013.2.370. URL: http://e-notabene.ru/al/article_370.html

27. Кабанов П.А.. Правовое регулирование организации и проведения антикоррупционного мониторинга на муниципальном уровне // Административное и муниципальное право. - 2013. - № 5. - C. 104-107. DOI: 10.7256/1999-2807.2013.05.9

28. Кабанов П.А.. Правовое регулирование антикоррупционного мониторинга в субъектах Российской Федерации: проблемы и перспективы // Административное и муниципальное право. - 2013. - № 4. - С. 104-107. DOI: 10.7256/19992807.2013.04.8

29. Кабанов П.А. Организационно-правовые аспекты прокурорского надзора за созданием и организацией деятельности Комиссий по соблюдению требований к служебному поведению государственных (муниципальных) служащих и урегулированию конфликта интересов // NB: Административное право и практика администрирования. - 2013. - № 1. - C.1-11. DOI: 10.7256/2306-9945.2013.1.405. URL: http://e-notabene.ru/al/article_405.html

30. Кабанов П.А. Политическая преступность в России: криминологический анализ исторического развития // NB: Вопросы права и политики. - 2013. - № 1. - C.285-304. DOI: 10.7256/2305-9699.2013.1.474. URL: http://e-notabene.ru/lr/article_474.html

31. Кабанов П.А. Криминологическая концепция личности политического преступника // NB: Вопросы права и политики. - 2013. - № 3. - С.239-257. DOI: 10.7256/2305-9699.2013.3.584. URL: http://e-notabene.ru/lr/article_584.html

32. Кабанов П.А.. Президиум Совета при Президенте Российской Федерации и образованные им рабочие группы и комиссия как федеральные специализированные антикоррупционные органы: правовое регулирование и вопросы повышения эффективности их деятельности // Административное и муниципальное право. - 2012. - № 11. - С. 104-107.

33. Кабанов П.А. Политическая преступность как политико-криминологическая категория // NB: Вопросы права и политики. - 2013. - № 2. - C.247-273. DOI: 10.7256/2305-9699.2013.2.535. URL: http://e-notabene.ru/lr/article_535.html

34. Кабанов П.А. Криминальная политическая виктимология как межотраслевая криминологическая теория: понятие, предмет, структура и перспективы развитя в современной России // NB: Вопросы права и политики. - 2012. - № 5. - C.218-232. DOI: 10.7256/2305-9699.2012.5.201. URL: http://e-notabene.ru/lr/article_201.html

35. Кабанов П.А.. Процедурные вопросы ознакомления с материалами, поступившими на рассмотрение Комиссии по соблюдению требований к служебному поведению государственных (муниципальных) служащих и урегулированию конфликта интересов // Административное и муниципальное право. - 2012. - № 10. - С. 104-107.

36. Кабанов П.А., Гарипов И.М.. Виктимологическая характеристика «государственной коррупции» в Республике Татарстан // Административное и муниципальное право. - 2012. - № 9. - С. 104-107.

37. Кабанов П.А.. Процессуальные основания и порядок отмены обязательных решений, принимаемых Комиссиями по соблюдению требований к служебному поведению государственных гражданских (муниципальных) служащих и урегулированию конфликта интересов // Административное и муниципальное право. - 2012. - № 7. - С. $104-107$.

38. Кабанов П.А.. Прокурорский надзор за формированием и деятельностью Комиссией по соблюдению требований к служебному поведению государственных (муниципальных) служащих и урегулированию конфликта интересов // Административное и муниципальное право. - 2012. - № 6. - С. 104-107.

39. Кабанов П.А.. О требованиях к членам Комиссий по соблюдению требований к служебному поведению государственных гражданских служащих и урегулированию конфликта интересов не занимающим должности государственной службы // Административное и муниципальное право. - 2012. - № 4. - С. 104-107.

40. Кабанов П.А.. Основания и порядок вывода членов Комиссий по соблюдению требований к служебному поведению государственных (муниципальных) служащих и урегулированию конфликта интересов из их состава // Административное и муниципальное право. - 2012. - № 3. - С. 104-107.

41. Кабанов П.А.. Прекращение производства по материалам, поступающим на рассмотрение Комиссий по соблюдению требований к служебному поведению государственных (муниципальных) служащих и урегулированию конфликта интересов: основания и порядок // Административное и муниципальное право. - 2012. - № 1. - С. 104-107. 
42. Кабанов П.А.. Правовое регулирование мониторинга эффективности деятельности Комиссий по соблюдению требований к служебному поведению государственных (муниципальных) служащих и урегулирования конфликта интересов в Республике Татарстан: опыт, проблемы и перспективы // Административное и муниципальное право. - 2012. - № 2. - С. 104-107

\section{References (transliterated):}

1. Akhmetova S.A. Obshchestvennoe obsuzhdenie «Innovatsionnaya politika v Khabarovskom krae» // Uchenye zapiski Komsomol'skogo-na-Amure gosudarstvennogo tekhnicheskogo universiteta. - 2014. - T.1. - №2 - - S.117-118.

2. Gainutdinova G.Kh., Mingazova N.M. Razlichiya v protsedurakh obshchestvennykh slushanii i obshchestvennykh slushanii // Ekologicheskii konsalting. - 2012. - №2. - S.15-21.

3. Zakharov A.K. Obshchestvennoe obsuzhdenie i protsedura prinyatiya i vneseniya izmenenii v ustav gorodskogo okruga // Yurist"'Pravoved". - 2011. - №5 (148). - S.98-100.

4. Leonov Yu.S. Ob obshchestvennom obsuzhdenii strategii gosudarstvennoi natsional'noi politiki Rossiiskoi Federatsii // Sovremennye issledovaniya sotsial'nykh problem. - 2013. - №1 (21).

5. Lipchinskaya M.A. Ob obshchestvennom obsuzhdenii zakonoproektov kak forma uchastiya grazhdan Rossiiskoi Federatsii v upravlenii delami gosudarstva // Pravovaya politika i pravovaya zhizn’. - 2011. - №2. - S.12-18.

6. Okolesnova O.A. Informatsionno-pravovye aspekty obshchestvennykh obsuzhdenii kak formy obshchestvennogo kontrolya // European Social Science Journal. - 2012. - №11-1 (27). - S.537-549.

7. Poroshin S.A. Korruptsiya v sisteme gosudarstvennykh zakupok: problemy i puti vykhoda // Voprosy upravleniya. - 2013. - №2 (4). - S.051-057.

8. Sivitskii V.A. Obshchestvennye obsuzhdeniya zakonoproektov: demokratiya ili gosudarstvennyi ratsionalizm // Yuridicheskaya tekhnika. - 2014. - №8. - S.393-396.

9. Khokhlova E.A. Obshchestvennoe obsuzhdenie zakonoproektov i vazhneishikh voprosov gosudarstvennoi i/ili obshchestvennoi zhizni: konstitutsionno-pravovoe regulirovanie // Konstitutsionnoe i munitsipal’noe pravo. - 2013. - №4. - S.47-59.

10. Astanin V.V. Ob effektivnykh mekhanizmakh vzaimodeistviya gosudarstva s grazhdanskim obshchestvom v sfere protivodeistviya korruptsii. // Administrativnoe i munitsipal'noe pravo. - 2011. - 4. - C. 5-8.

11. Kharitonov A.N. Retsenziya na knigu: N.A. Kolomyttsev, O.N. Kolomyttseva Sovremennye problemy obshchestvennogo kontrolya v Rossii: monografiya. - SPb.: Izdatel'stvo Yuridicheskogo instituta (Sankt-Peterburg). 2014. - 220 s. // Administrativnoe i munitsipal'noe pravo. - 2014. - 7. - C. 696-699. DOI: 10.7256/1999-2807.2014.7.12076.

12. Kabanov P.A. Antikorruptsionnyi monitoring v munitsipal'nom obrazovanii: pravovoe regulirovanie, organizatsiya i provedenie // NB: Administrativnoe pravo i praktika administrirovaniya. - 2013. - № 6. - S.44-53. DOI: 10.7256/2306-9945.2013.6.9016. URL: http://e-notabene.ru/al/article_9016.html

13. Kabanov P.A.. Antikorruptsionnoe obrazovanie kak pravovaya kategoriya regional'nogo antikorruptsionnogo zakonodatel'stva: opyt kriticheskogo analiza // Politseiskaya deyatel'nost'. - 2014. - № 1. - S. 104-107. DOI: 10.7256/2222-1964.2014.1.10653

14. Kabanov P.A. Pravovye sredstva formirovaniya i obespecheniya realizatsii gosudarstvennoi politiki protivodeistviya korruptsii v sub",'ektakh Rossiiskoi Federatsii: nekotorye voprosy povysheniya kachestva // NB: Voprosy prava i politiki. - 2014. - № 8. S.36-47. DOI: 10.7256/2305-9699.2014.8.12004. URL: http://e-notabene.ru/lr/article_12004.html

15. Kabanov P.A. Yuridiko-lingvisticheskaya neopredelennost' kak predmet antikorruptsionnoi ekspertizy normativnykh pravovykh aktov i proektov normativnykh pravovykh aktov // NB: Administrativnoe pravo i praktika administrirovaniya. - 2014. - № 3. S.61-71. DOI: 10.7256/2306-9945.2014.3.12055. URL: http://e-notabene.ru/al/article_12055.html

16. Kabanov P.A. Kompromissy pri realizatsii gosudarstvennoi politiki Rossiiskoi Federatsii v sfere protivodeistviya korruptsii kak sredstva razresheniya pravovykh protivorechii // NB: Voprosy prava i politiki. - 2014. - № 7. - S.66-78. DOI: 10.7256/23059699.2014.7.12702. URL: http://e-notabene.ru/lr/article 12702.html

17. Kabanov P.A. Organizatsiya i osushchestvlenie vedomstvennogo kontrolya za realizatsiei gosudarstvennoi politiki protivodeistviya korruptsii v regionakh Rossiiskoi Federatsii // NB: Voprosy prava i politiki. - 2014. - № 6. - S.130-145. DOI: 10.7256/23059699.2014.6.12236. URL: http://e-notabene.ru/lr/article_12236.html

18. Kabanov P.A. Antikorruptsionnye programmy sub"ektov Rossiiskoi Federatsii kak sredstva protivodeistviya korruptsii: opyt kriticheskogo analiza // NB: Problemy obshchestva i politiki. - 2014. - № 5. - S.42-70. DOI: 10.7256/2306-0158.2014.5.12103. URL: http://e-notabene.ru/pr/article_12103.html

19. Kabanov P.A.. Retsenziya na knigu: Budatarov S.M. Antikorruptsionnaya ekspertiza pravovykh aktov i ikh proektov: ponyatie, poryadok provedeniya: spetsializirovannyi uchebnyi kurs / S.M. Budatarov; Saratovskii Tsentr po issledovaniyu problem organizovannoi prestupnosti i korruptsii. - Saratov: Izd-vo FGBOU VPO «Saratovskaya gosudarstvennaya yuridicheskaya akademiya», 2013. - 120 s. // Administrativnoe i munitsipal'noe pravo. - 2013. - № 7. - S. 104-107. DOI: 10.7256/1999-2807.2013.7.9054

20. Kabanov P.A. Kvalifikatsionnye trebovaniya k chlenam Komissii po soblyudeniyu trebovanii k sluzhebnomu povedeniyu gosudarstvennykh (munitsipal'nykh) sluzhashchikh i uregulirovaniyu konflikta interesov ne zanimayushchim dolzhnosti gosudarstvennoi (munitsipal'noi) sluzhby // NB: Administrativnoe pravo i praktika administrirovaniya. - 2013. - № 3. - S.25-33. DOI: 10.7256/2306-9945.2013.3.657. URL: http://e-notabene.ru/al/article_657.html

21. Kabanov P.A.. Organizatsionno-pravovye voprosy podgotovki i osushchestvleniya antikorruptsionnogo monitoringa v sub"ektakh Rossiiskoi Federatsii // Administrativnoe i munitsipal'noe pravo. - 2013. - № 7. - S. 104-107. DOI: 10.7256/1999-2807.2013.7.8934 


\section{Право и политика $10(178) \cdot 2014$}

22. Kabanov P.A. Oznakomlenie s materialami uchastnikov zasedaniya Komissii po soblyudeniyu trebovanii k sluzhebnomu povedeniyu gosudarstvennykh (munitsipal'nykh) sluzhashchikh i uregulirovaniyu konflikta interesov, postupivshimi na rassmotrenie: protsedurnye voprosy // NB: Administrativnoe pravo i praktika administrirovaniya. - 2012. - № 1. - S.17-23. DOI: 10.7256/23069945.2012.1.376. URL: http://e-notabene.ru/al/article_376.html

23. Kabanov P.A.. Ob obespechenii realizatsii otdel'nykh polozhenii antikorruptsionnogo zakonodatel'stva na munitsipal'nom urovne // Administrativnoe i munitsipal'noe pravo. - 2013. - № 6. - S. 104-107. DOI: 10.7256/1999-2807.2013.06.11

24. Kabanov P.A. Diskussionnye voprosy sovremennoi rossiiskoi politicheskoi kriminologii // NB: Voprosy prava i politiki. - 2012. - № 4. - S.240-267. DOI: 10.7256/2305-9699.2012.4.220. URL: http://e-notabene.ru/lr/article_220.html

25. Kabanov P.A. Prezidium Soveta pri Prezidente Rossiiskoi Federatsii i obrazuemye im rabochie organy kak vysshie federal'nye spetsializirovannye antikorruptsionnye uchrezhdeniya: voprosy povysheniya kachestva pravovogo regulirovaniya i effektivnosti ikh deyatel'nosti // NB: Administrativnoe pravo i praktika administrirovaniya. - 2013. - № 2. - S.91-104. DOI: 10.7256/23069945.2013.2.370. URL: http://e-notabene.ru/al/article_370.html

26. Kabanov P.A.. Pravovoe regulirovanie organizatsii i provedeniya antikorruptsionnogo monitoringa na munitsipal'nom urovne // Administrativnoe i munitsipal'noe pravo. - 2013. - № 5. - S. 104-107. DOI: 10.7256/1999-2807.2013.05.9

27. Kabanov P.A.. Pravovoe regulirovanie antikorruptsionnogo monitoringa v sub"ektakh Rossiiskoi Federatsii: problemy i perspektivy // Administrativnoe i munitsipal'noe pravo. - 2013. - № 4. - S. 104-107. DOI: 10.7256/1999-2807.2013.04.8

28. Kabanov P.A. Organizatsionno-pravovye aspekty prokurorskogo nadzora za sozdaniem i organizatsiei deyatel'nosti Komissii po soblyudeniyu trebovanii k sluzhebnomu povedeniyu gosudarstvennykh (munitsipal'nykh) sluzhashchikh i uregulirovaniyu konflikta interesov // NB: Administrativnoe pravo i praktika administrirovaniya. - 2013. - № 1. - S.1-11. DOI: 10.7256/23069945.2013.1.405. URL: http://e-notabene.ru/al/article_405.html

29. Kabanov P.A. Politicheskaya prestupnost' v Rossii: kriminologicheskii analiz istoricheskogo razvitiya // NB: Voprosy prava i politiki. - 2013. - № 1. - S.285-304. DOI: 10.7256/2305-9699.2013.1.474. URL: http://e-notabene.ru/lr/article_474.html

30. Kabanov P.A. Kriminologicheskaya kontseptsiya lichnosti politicheskogo prestupnika // NB: Voprosy prava i politiki. - 2013. - № 3. - S.239-257. DOI: 10.7256/2305-9699.2013.3.584. URL: http://e-notabene.ru/lr/article_584.html

31. Kabanov P.A.. Prezidium Soveta pri Prezidente Rossiiskoi Federatsii i obrazovannye im rabochie gruppy i komissiya kak federal'nye spetsializirovannye antikorruptsionnye organy: pravovoe regulirovanie i voprosy povysheniya effektivnosti ikh deyatel'nosti // Administrativnoe i munitsipal'noe pravo. - 2012. - № 11. - S. 104-107.

32. Kabanov P.A. Politicheskaya prestupnost' kak politiko-kriminologicheskaya kategoriya // NB: Voprosy prava i politiki. - 2013. - № 2. - S.247-273. DOI: 10.7256/2305-9699.2013.2.535. URL: http://e-notabene.ru/lr/article_535.html

33. Kabanov P.A. Kriminal'naya politicheskaya viktimologiya kak mezhotraslevaya kriminologicheskaya teoriya: ponyatie, predmet, struktura i perspektivy razvitya v sovremennoi Rossii // NB: Voprosy prava i politiki. - 2012. - № 5. - S.218-232. DOI: 10.7256/2305-9699.2012.5.201. URL: http://e-notabene.ru/lr/article_201.html

34. Kabanov P.A.. Protsedurnye voprosy oznakomleniya s materialami, postupivshimi na rassmotrenie Komissii po soblyudeniyu trebovanii k sluzhebnomu povedeniyu gosudarstvennykh (munitsipal'nykh) sluzhashchikh i uregulirovaniyu konflikta interesov // Administrativnoe i munitsipal'noe pravo. - 2012. - № 10. - S. 104-107.

35. Kabanov P.A., Garipov I.M.. Viktimologicheskaya kharakteristika «gosudarstvennoi korruptsii» v Respublike Tatarstan // Administrativnoe i munitsipal'noe pravo. - 2012. - № 9. - S. 104-107.

36. Kabanov P.A.. Protsessual'nye osnovaniya i poryadok otmeny obyazatel'nykh reshenii, prinimaemykh Komissiyami po soblyudeniyu trebovanii k sluzhebnomu povedeniyu gosudarstvennykh grazhdanskikh (munitsipal'nykh) sluzhashchikh i uregulirovaniyu konflikta interesov // Administrativnoe i munitsipal'noe pravo. - 2012. - № 7. - S. 104-107.

37. Kabanov P.A.. Prokurorskii nadzor za formirovaniem i deyatel'nost'yu Komissiei po soblyudeniyu trebovanii k sluzhebnomu povedeniyu gosudarstvennykh (munitsipal'nykh) sluzhashchikh i uregulirovaniyu konflikta interesov // Administrativnoe i munitsipal'noe pravo. - 2012. - № 6. - S. 104-107.

38. Kabanov P.A.. O trebovaniyakh k chlenam Komissii po soblyudeniyu trebovanii k sluzhebnomu povedeniyu gosudarstvennykh grazhdanskikh sluzhashchikh i uregulirovaniyu konflikta interesov ne zanimayushchim dolzhnosti gosudarstvennoi sluzhby // Administrativnoe i munitsipal'noe pravo. - 2012. - № 4. - S. 104-107.

39. Kabanov P.A.. Osnovaniya i poryadok vyvoda chlenov Komissii po soblyudeniyu trebovanii k sluzhebnomu povedeniyu gosudarstvennykh (munitsipal'nykh) sluzhashchikh i uregulirovaniyu konflikta interesov iz ikh sostava // Administrativnoe i munitsipal'noe pravo. - 2012. - № 3. - S. 104-107.

40. Kabanov P.A.. Prekrashchenie proizvodstva po materialam, postupayushchim na rassmotrenie Komissii po soblyudeniyu trebovanii k sluzhebnomu povedeniyu gosudarstvennykh (munitsipal'nykh) sluzhashchikh i uregulirovaniyu konflikta interesov: osnovaniya i poryadok // Administrativnoe i munitsipal'noe pravo. - 2012. - № 1. - S. 104-107.

41. Kabanov P.A.. Pravovoe regulirovanie monitoringa effektivnosti deyatel'nosti Komissii po soblyudeniyu trebovanii k sluzhebnomu povedeniyu gosudarstvennykh (munitsipal'nykh) sluzhashchikh i uregulirovaniya konflikta interesov v Respublike Tatarstan: opyt, problemy i perspektivy // Administrativnoe i munitsipal'noe pravo. - 2012. - № 2. - S. 104-107 